Volume rog of the Yale Series of Younger Poets 
This page intentionally left blank 
ANSEL ELKINS

\section{Blue Yodel}

FOREWORD BY CARL PHILLIPS

Yale UNIVERSITY PRESS

NEW HAVEN AND LONDON 
Published with assistance from a grant to honor James Merrill and with assistance from the Louis Stern Memorial Fund.

Copyright () 2015 by Yale University.

Foreword copyright (C) 2015 by Carl Phillips.

All rights reserved. This book may not be reproduced, in whole or in part, including illustrations, in any form (beyond that copying permitted by Sections 107 and 108 of the U.S. Copyright Law and except by reviewers for the public press), without written permission from the publishers.

Yale University Press books may be purchased in quantity for educational, business, or promotional use. For information, please e-mail sales.press@yale.edu (U.S. office) or sales@yaleup.co.uk (U.K. office).

Set in Janson Oldstyle type by Tseng Information Systems, Inc. Printed in the United States of America.

Library of Congress Cataloging-in-Publication Data Elkins, Ansel, r982[Poems. Selections]

Blue yodel / Ansel Elkins ; foreword by Carl Phillips. pages $\mathrm{cm}$. - (Yale series of younger poets; volume I09) ISBN 978-o-300-21003-3 (cloth : alk. paper) ISBN 978-0-300-2IOO2-6 (pbk. : alk. paper)

I. Title.

PS3605.L4I7A6 20I5

$8 \mathrm{II}^{\prime} .6-\mathrm{dc2} 3 \quad 2014031909$

A catalogue record for this book is available from the British Library. This paper meets the requirements of ANSI/NISO Z39.48-I992 (Permanence of Paper).

$\begin{array}{llllllllll}\text { Iо } & 9 & 8 & 7 & 6 & 5 & 4 & 3 & 2 & \text { I }\end{array}$ 
To Scarlett Saavedra

and

Ken Elkins,

who gave me life and taught me joy 
This page intentionally left blank 
A pair of eyes was painted on my cheeks as a sign that I could see in more ways than one.

-Zora Neale Hurston 
This page intentionally left blank 